Path. Microbiol. 1967;30:I-X

\title{
Contents, Vol. 30, 1967
}

Pathologia et Microbiologia

Pathologia et Microbiologia

Schweiz. Zeitschr. für allg. Pathologie und Bakteriologie

Revue Suisse de Pathologie generate et de Bactériologie

Swiss Journal of General Pathology and Bacteriology

Condiderunt: A. v. ALBERTINI - A. GRUMBACH - H. MOOSER

Offizielles Organ der Schweiz. Mikrobiologischen Gesellschaft

Organe officiel de la Société Suisse de Microbiologie

Official Organ of the International Society of Geographical Pathology

R. SILBERBERG $\uparrow$, Saint Louis, Mo. A. WERTHEMANN, Basel

H. CHIARI, Wien

H. COTTIER, Bern

H. FEY, Bern

J. FIRKET, Liège

C. HALLAUER, Bern

J. LINDENMANN, Zurich

COLLABORATORES

A. L. OLITZKI, Jerusalem R. H. REGAMEY, Geneve F. C. ROULET, Basel E.

RUTISHAUSER $\dagger$, Geneve

H. SMETANA, Washington R. TULASNE, Strasbourg E. UEHLINGER, Zurich M. WELSCH, Liège

REDACTORES A. GRUMBACH, Zurich J. R. RÜTTNER, Zurich

Vol. 30

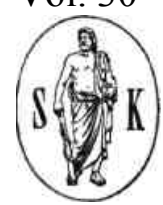

1967

\section{BASEL (Schweiz) S. KARGER NEW YORK}

Alle Rechte, insbesondere das der Übersetzung in fremde Sprachen, vorbehalten.

Ohne ausdrückliche Genehmigung des Verlages ist es auch nicht gestattet, dieses Buch oder Teile daraus auf photomechanischem Wege (Photokopie, Mikrokopie) zu vervielfãltigen.

(C)

Copyright 1967 by S. Karger AG., Basel. Printed in Switzerland by Buchdruckerei Friedrich Reinhardt AG., Basel Cliches: Aberegg-Steiner \& Cie. AG., Bern, und Steíner \& Cie. AG., Basel Index

Agnese, G.: The Prevalence of Heart Diseases Among the Population of the Hinterland of Genoa 610

Altman, S.: vide Brunner, D. 
Andreesco, Viorica: vide Barber, Cella

Arber, W. und Kühnlein, U.:

Mutationeller Verlust B-spezifischer Restriktion des Bakteriophagen

fd 946

Arber, W.: Les facteurs de resistance à des antibiotiques. Point de vue du généticien moléculaire 1007

Ashley, D. J. B.: Coronary Artery Disease in Wales 589

Auden, J.; Gruner, J.; Nüesch, J. and Knüsel, F.:

Some Statistical Methods in Nutrient Medium Optimalisation . . 858

Auriol, M.: vide Chomette, G.

Babußceac, Livia: vide Diosi, P.

Bänffer, J. R. J. and Franken, J. F.:

Immunization with Leucocidin Toxoid Against Staphylococcal

Infection 166

Barber, Cella; Andreesco, Viorica; Pozsgi, N. et Caffé, Ileana:

Sur les relations immunochimiques des Bordetelles $\quad 94$

Berndt, E.: $\quad$ vide Schröter, J.

Bessede, P.: vide Grosgogeat, Y.

Betz, E. H.: Myocardial Infarction Autopsies in Belgium 585

Bianchi, L.; Della Torre, B. and Martinazzi, M.:

Fatal Pancreatic Necrosis in Human Phycomycosis (with Plate I) . 15

Bienz, K.: Die Entwickulng von Trypanosomen in verschiedenen Wirten . . 867

Boer, J. de: vide Thomasson, H. J.

Böttcher, C. J. F.: Chemical Factors in Atherogenesis

619

Bosman, C. and Cavaliere, P.:

Biometrically Revealed Splenic Differences between Thalassemia,

Hereditary Spherocytosis and Elliptocytosis 35

Breitfellner, G. and Neuhold, R.:

The Geographical Distribution of Heart Infarct in Austria 593

Breitfellner, G. and Neuhold, R.:

Der Herzinfarkt im Sektionsgut eines Jahres am Allgemeinen

Krankenhaus in Wien 599

Brocheriou, C.: vide Chomette, G.

Bruijn, W. C de and Schornagel, H. E.:

The Ultrastructure of Experimental Atheromatosis in Rabbits . . 671

Brunner, D.; Manelis, G. and Altman, S.:

Physical Activity, Lipoproteins and Ischemic Heart Disease .... 648

Caffé, Ileana: vide Barber, Cella

Cavaliere, P.: vide Bosman, C.

Chamay, A. et Rosner, P.:

Sorties cortico-surrénaliennes expérimentales dans le tissu adipeux du rat au moyen d'autogreffes de capsules et de surrénales décapsulées

(Etude au microscope optique)

Chodat, F.: vide El-Sabeh, A.

Chomette, G.; Delarue, J.; Brocheriou, C.; Auriol, M. et Pinaudeau, Y.:

L'infarctus du myocarde chez le vieillard. Dénombrement nécropsiqne 
dans une population d'hospice

Chuit, Claude Françoise:

Adsorption of Phage $\lambda \mathrm{cb} 2$ in Tetracycline-resistant Escherichia

coli K12

972

Ciuca, A. and Jucovski, V.:

Geographical Distribution of Cardiovascular Diseases and Life Span 794 Combépine, G. et

Turian, G.:

Métabolisme de la glycine et conidiation du Neurospora crassa . . 953

David, Camelia: vide Diosi, P.

Delarue, J.: vide Chomette, G.

Della Torre, B.: vide Bianchi, L.

Denis, Colette : Emploi de particules d'acryl dans le sérodiagnostic de la toxoplasmose 981

D'Eramo, N.: The Epidemiology of Atherosclerosis in the Zone of Marsica (Abruzzi, Italy) 603

Dietrich, F. M. and Dukor, P.:

The Immune Response to Heterologous Red Cells in Mice. III.

Cyclophosphamide-induced Tolerance to Multispecies Red Cells . 909 Dimow, I. und

Slavtschew, R.:

Versuche der Experimentalinfizierung von Schlangen Vípera ammo-

dytes ammodytes mit Salmonella- und Arizonabakterien 495

Diosi, P.; Nevinglovschi, Olimpia; Babu§ceac, Livia and David, Camelia:

Incidence of Cytomegalic Infection in Man 453

Drãgudãnesco, Ch.:

vide Ilea, $\mathrm{T}$.

Drory, Shoshana: vide Groen, J. J.

Dukor, P.: vide Dietrich, F. M.

El-Sabeh, A.; Greppin, H. et Chodat, F.:

L'alternative respiratoire terminale et sa correlation avec les états

$\mathrm{R}$ et $\mathrm{S}$ de Pseudomonas fluorescens 924

Enachesco, D.: vide Ilea, T.

Engelbrecht, E.: Localisation dans les larves de Trichínella spiralis des facteurs

communs à Ascaris suis et à Salmonella bareílly. Etude en fluorescence 989 Engeler, M. L.: vide Rüttner, J. R. Enticknap, J. B.: vide Gooding, P. G. Erkelens, A. D.: The Prevalence of Arteriosclerotic Heart Disease in the Netherlands.

A Method to Evaluate Morbidity $\quad 800$

Ettlinger, L.: vide Glättli, $\mathrm{H}$.

Ettlinger, L.: vide Monard, D.

Farrer-Brown, G. and Wartman, W. B.:

The Microvasculature of the Cardiac Ventricles 695

Felix, H.: vide Sandritter, W.

Fey, H.: $\quad$ vide Nicolet, J.

Fixa, B.; vide Langr, F.

Fixa, B.: $\quad$ vide Parízek, J.

Francis, T., Jr.: Epidemiological Aspects of Coronary Heart Disease 752

Franken, J. F.: vide Bänffer, J. R. J.

French J. E.: Thrombosis in Arteries: the Role of the Blood Platelets 
Sacks, M. I. and Vlodaver, Z.:

An Autopsy Study of Myocardial Infarction in Israel

570

Sandkitter, W. and Felix, H.:

Geographical Pathology of Fatal Lung Embolism 742

Schebrer, M.: vide Knüsel, F.

Scherrer, M.: vide Nüesch, J.

Schettxer, und Hild, R.:

Koronarsklerose und Myokardinfarkt in der Westdeutschen Bundes-

republik 1945-1965 766

Schiess, B.: vide Knüsel, F.

Schmid, K.: vide Knüsel, F.

Schmidtmann, M.: Studien zur Ätiologie der Herzschlagaderverkalkung

732

SCHOENMACKERS, J.:

Bericht über die Häufigkeit von Koronarsklerose und Infarkt an

Hand des Materials von 14 deutschen Pathologischen Instituten . . 561 Schornagel, H. and

Rüttner, J. R.:

Introduction to the Myocardial Infarction Inquiry 517

Schornagel, H. E.: vide Bruijn, W. C. de Schroder, J. and Berndt, E.:

Factors Simulating an Increasing Incidence of Myocardial Infarction 789 SchÜtte, H. E.: The

Relationship Between Plaque Localization and the Vasculariza-

tion of the Human Abdominal Aorta 685

Schuh, D.: vide KuNZe, K. D.

Schweizer, H.: vide Güthert, H. Selye, H.; Rohan, P. and Pahk, U. S.:

Systemic vs. Topical Conditioning for Acute Necrosis 257

SILBERBERG, M. (†); SILBERBERG, RUTH and HASLER, MARY:

Effects of Fasting and Refeeding on the Ultrastructure of Articular

Cartilage 283

SILBERBERG, RüTH: vide SILBERBERG, M.

Slawtschew, R.: vide Dimov, I.

Summers, S. C.: Systematized Nomenclature of Pathology 826

Solymoss, B.: vide Varga, S.

Sprössig, M.: vide Güthert, H.

Spycher, M. A.: Zur Frühembryogenese der Leber. Elektronenmikroskopische Unter-

suchungen an der embryonalen Rattenleber 303

Sternby, N. H.: Discussion on International Studies of Myocardial Infarction . . 817

Sternby, N. H.: Problems in Geographical Comparison of Autopsy Findings .... 817

StÖtzner, H.: Beitrag zur Cryptococcose, insbesondere zu ihrer spezifischen histo-

logischen Nachweismöglichkeit und zur Meningoencephalitis crypto-

coccica 367

Stofer, A. R.: Experimentelle, lokalisierbare und steuerbare Thermonekrose des

Herzmuskels an der Ratte 146

Stoner, R. D.: vide Hess, M. W.

Studer, A. und Lorez, H. P.:

Spätveränderungen nach Überdehnung der Aorta abdominalis des

Kaninchens bei gleichzeitiger distaler Stenosierung 129

Tandon, R. N.: vide Ghosh, A. K. Thomasson, H. J.; Boer, J. de and Iongh, H. de: 
Influence of Dietary Fats on Plasma Lipids 629

Ghosh, A. K. and Tandon, R. N.:

Utilization of Alcohols by some Anthracnose Fungi

Giuffrè, L.: vide Priolisi, A.

Glättli, H. und Ettlinger, L.:

Aethanol als Energie-, aber nicht als Kohlenstoffquelle bei Acetomonas

oxydans $\quad 918$

Godinger, D.: vide Olitzki, A. L.

Goldberg, G. M. and Kozenitzky, I. L.:

The Lymphatics of the Heart in Normal and Pathological States . . 738

Gooding, P. G. and Enticknap, J. B.:

Platelet Size and Behaviour 665

Greppin, H.: vide El-Sabeh, A.

Gresham, G. A.: vide Howard, A.

Groen, J. J. and Drory, Shoshana:

Influence of Psychosocial Factors on Coronary Heart Diseases. A

Comparison of Autopsy Findings with the Results of a Sociological

Questionnaire 779

Groen, J. J.: vide Kallner, G.

Grosgogeat, Y.; Bessede, P. et Humbert, J.:

L'infarctus myocardique du sujet jeune à evolution mortelle. Etude

anatomique 727

Gruner, J.: $\quad$ vide Auden, J.

Gruner, J.: $\quad$ vide Nüesch, J.

Güthert, H.; Sprössig, Y.; Wöckel, W.; Meerbach, W. und Schweizer, H.:

Zur Varizellenviruspneumopathie 353

Haas, H.: vide Olitzki, A. L.

Hagi-Paraschiv-Dosius, Liliana and Iliescu, C. C.:

Tissular Reactivity of the Vascular Wall and its Importance in the

Production of Acute Coronary Occlusion 718

Hasler, Mary: vide Silberberg, M.

Havlícek, J. and Havlícková, H.:

Antigenic Structure of Streptococcus pyogenes L Forms 469

Havlícková, H.: vide Havlícek, J.

Heggtweit, H. A.: The Role of Coronary Ostial Stenosis in the Etiology of Myocardial

Infarction $\quad 716$

Henschen, F.: Arteriosclerosis in Sweden 805

Herrmann, W. R.: vide Kunze, K. D.

Hess, M. W. and Stoner, R. D.:

Attempts to Induce Immunological Tolerance to Tetanus Toxoid

and Xenogeneic Lymphoid Cells in Normal and Neonatally Thymec-

tomized Mice 155

Hild, R.: $\quad$ vide Schettler, G.

Himbert, J.: vide Grosgogeat, Y.

Hodel, C.: $\quad$ Fermenthistochemische Befunde an Riesenzellen in Talkgranulomen

der Ratte 27 
Honigman, A.:vide Olitzki, A. L.

Howard, A. N.; Jennings, I. W. and Gresham, G. A.:

Atherosclerosis in Pigs Obtained from Two Centres Differing in

Hardness of Water Supply 676

Hradil, I.: $\quad$ vide Langr, F.

Hradil, L: $\quad$ vide Parízek, J.

Hütter, R.: vide Monard, D.

HUGUENIN-VIRCHAUX, M.:

Le facteur vasculaire dans les alterations de la moelle osseuse et de

son cadre ostéocartilagineux. Etude expérimentale sur la rotule de

lapin 404

Huszar, T.: vide Ilea, T.

Iliescu, C. C.: vide Hagi-Paraschiv-Dosius, Liliana

Ilea, T.; Enächesco, D.; Huszar, T.; Lemneanu, Elisabeta; Luculesco, S.;

Mihäilesco, D. et Drãgudãnesco, Gh. :

Facteurs de risque à propos des décès par infarctus myocardique

dans la ville de Bucarest $\quad 606$

Iongh, H. de: vide Thomasson, H. J.

Israeli, M.: vide Olitzki, A. L.

Jelonek, A.: The Importance of Decalcification in the Treatment of Tuberculosis.

II. Uptake of $45 \mathrm{Ca}$ by Tuberculous Organs of Guinea Pigs 201

Jennings, I. W.: Vascular Changes in Gastric Ulcers 747

Jennings, I. W.: vide Howard, A. N.

Jójárt, G.: $\quad$ vide KovÁcs, E.

Jucovski, V.: vide Ciuca, A.

Jung, M.: vide Krech, U.

Kästli, P.: Das Verhalten von Staphylokokken im Kuheuter 849

Kagan, A. R. and Uemura, K.:

Limitations of these Studies and Designs for Future Studies.... 824

Kallner, G. and Groen, J. J.:

Coronary and Cerebral Atherosclerosis Among Western and Eastern

Immigrants in Israel 777

Kayser, F.-H.: Zur Resistenzprüfung der Staphylokokken gegen Penicillinase-feste Penicilline und Cephalosporine $\quad 381$

Klein, P. A.: Antibody-Mediated Immunity to Transplantable Tumors Following

Reovirus Oncolysis 222

Klinger, K.: vide Nicolet, J.

Knapp, W. und Lebek, G.:

Übertragung der infektiösen Resistenz auf Pasteurellen 103

Knüsel, F.; Nüesch, J.; Scherrer, M. und Schmid, K.:

Einfluß von Lanthionin auf das Wachstum einer Diaminopimelin-

säure-heterotrophen Mutante von Excheríchía coli 871

Knüsel, F.; Nüesch, J.; Scherrer, M. und Schiess, B.:

Der Einfluß von Siderochromen auf die Inkorporation nieder-

molekularer Substanzen in Ganzzellen von Bakterien $\quad 900$

Knüsel, F.: $\quad$ vide Auden, J. 
Knüsel, F.: $\quad$ vide Nüesch, J.

Komárková, Olga: vide Langr, F.

Komárková, Olga: vide Parízek, J.

Kontomichalou, P.: Studies on Resistance Transfer Factors

71

Kontomichalou, P.: Studies on Resistance Transfer Factors. II. Transmissible Resistance

to Eight Antibacterial Drugs in a Strain of Escheríchía coli .... 185

Kovãcs, E.; Mazarean, H. H. and Jójárt, G.:

The Effect of ACTH on the Catalase Activity of the Adrenal Gland

in in vivo Experiments. Preliminary Communication

Kozenitzky, I. L.: vide Goldberg, G. M.

Krauland, W.: Types of Coronary Occlusion 709

Krech, U. and Jung, M.:

Acute Viral Respiratory Infections in Switzerland $1967 \quad 1050$

Krech, U. und Paccaud, M.:

Vergleichende Untersuchungen über die Häufigkeit von Mycoplasma

pneumoniae-ïnfektion in Genf und St. Gallen 1037

Kühnlein, U.: vide Arber, W.

Kunze, K. D.; Schuh, D. und Herrmann, W. R.:

Die Bedeutung der Fuchsinophilie für den Frühnachweis des experi

mentellen Herzinfarktes der Ratte 393

Langr, F.; Fixa, B.; Komárková, Olga; Parízek, J.; Vejbora, 0. and Hradil, I.:

Morphology of the Gastric Mucosa of the Dog after Immunization with

Autologous Gastric Juice. I. Histological Study 419

Langr, F.: $\quad$ vide Parízek, J.

Lebek, G.: Medizinische Aspekte der infektiösen Antibiotika-Resistenz gramnegativer Darmbakterien 1015

Lebek, G.: vide Knapp, W.

Lemneanu, Elisabeta:

vide Ilea, $\mathrm{T}$.

Lendrum, A. C.: Deposition of Plasmatic Substances in Vessel Walls 681

Lewicki, Z.: Atherosclerosis and Myocardial Infarction in the Autopsy Material

Deriving from Big Towns in Poland During one Year $\quad 579$

Likar, M.: $\quad$ vide Ravnik, C.

Lokez, H. P.: vide Studer, A.

Luculesco, S.: vide Ilea, T.

Manelis, G.: vide Brunner, D.

Marthaler, Th. : vide Rüttner, J. R.

Martinazzi, M.: vide Bianchi, L.

Mazarean, H. H.: vide KovÁcs, E.

Meerbach, W.: vide Güthert, $\mathrm{H}$.

Meier-Ruge, W.: Der Aussagewert des experimentellen pathologischen Nierenbefundes

für die Pathologie der menschlichen Niere 266

Meyrath, J.: vide Ojha, M. N.

Mihãilesco, D.: vide Ilea, T.

Moberg, A.: Anatomical and Functional Aspects of Extracardial Anastomoses

to the Coronary Arteries 689 
Modde, H.: $\quad$ vide Pagon, S.

Monard, D.; Hütter, R. et Ettlinger, L.:

Auxotrophie dictée par la source d'énergie chez Acetobacter aceti . 966

Neuhold, R.: vide Breitfellner, G.

Nevinglovschi, Olimpia :

vide Diosi, P.

Nicolet, J.; Klingler, K. et Fey, H.:

Dermatophílus congolensis, agent de la streptotrichose du chamois . 831

Nohdheim, W. und Rieche, A.:

Beeinflussung des Atmungsstoffwechsels von kontinuierlich aerob

kultivierten Wuchshefezellen (Candida utilís) durch das Phosphatan-

gebot 175

Nüesch, J.; Grunder, J.; Knüsel, F. und Treichler, H. J.:

Cephalosporin C- und 7-Aminocephalosporansäure abbauende En

zyme aus Mikroorganismen 880

Nüesch, J.; Knüsel, F. und Scherrer, M.:

Der Einfluß von Siderochromen auf das Glutaminsäure bildende

Bakterium Brevibacterium flavum ATCC $14067 \quad 890$

Nüesch, J.: vide Auden, J.

Nüesch, J.: $\quad$ vide Knüsel, F.

Ojha, M. N. and Meyrath, J.:

Self Stimulation and Self Inhibition in Penicillium chrysogenum . 959

Olitzki, A. L.; Haas, H.; Godinger, D.; Israeli, M. and Honigman, A.:

Studies on Atypical Mycobacteria in Israel. I. Infections Caused by

Mycobacteríum fortuitum 433

Paccaud, M. F. and Paccaud, M.:

Influenza A/equi-2 Viruses Isolated in Switzerland, 1965-1966.

A Comparative Antigenic Study 999

Paccaud, M.: vide Krech, U.

Paccaud, M.: vide Paccaud, M. F.

Pagon, S. und Modde, H.:

Beobachtungen im Zusammenhang mit dem epidemischen Auftreten

Salmonella panatna 1966 in der Schweiz 1041

Pahk, U. S.: vide Selye, H.

Papaevangelou, G. and Papavassiliou, J.:

Comparison of Desoxyribonuclease Activity to some Other Criteria

of Staphylococcus Pathogenicity

59

Papavassiliou, J.: vide Papaevangelou, G.

Paradisi, F.: Mitochondrial Swelling Induced by Diphtheria Toxin in Cell Cultures 481

Parízek, J.; Fixa, B.; Komárková, Olga; Langr, F.; Hradil, I. and Vejbora, 0.:

Morphology of the Gastric Mucosa of the Dog after Immunization

with Autologous Gastric Juice. II. Histochemical Study 425

Parízek, J.: vide Langr, F.

Pinaudeau, Y.: vide Chomette, G.

Pozsgi, N.: vide Barber, Cella

Priolisi, A. and Giuffrè, L.: 
Immunoelectrophoretic Analysis of Serum Proteins of Patients

Affected by Kala-Azar 215

Rannie, I.: $\quad$ Report on the Survey of Heart Infarction in the United Kingdom . 557

Ravnik, C. and Likar, M.:

Antigens of the Oral Bacterial Flora in the Dental Pulp 208

Rieche, A.: vide Nordheim, W.

Robertson, W. B.: The International Atherosclerosis Project 810

Robertson, W.: Discussion on International Studies of Myocardial Infarction . . 817

Rohan, P.: vide Selye, H.

Rohan, P.: vide Varga, S.

Rosner, P.: vide Chamay, A.

Roszczyk, Emilia: The Susceptibility of Staphylococcus aureus Strains to Phage 87 (1380) 449

Rüttner, J. R.; Marthaler, Th. and Engeler, M. L.:

General Report on the Myocardial Infarction Inquiry of the I.S.G.P.

1964/65. Preliminary Data 521

Rüttner, J. R.: vide Schornagel, H.

Trembler, H. J.: vide Nüesch, J.

Turian, G.: $\quad$ vide Combépine, G.

Uemura, K.: vide Kagan, A. R.

VanÈcek, R.: Discussion on International Studies of Myocardial Infarction ... 817

Varga, S.; Solymoss, B. and Rohan, P.:

The Alterations of Venous Endothelium in Experimental Thrombosis

Produced by Catecholamines and Metals 139

Vejbora, O.: vide Langr, F.

Vejbora, 0.: vide Parízek, J.

Vihert, A. M.: Comparison of the Tendency to Develop Myocardial Infarction in

Some Communities in Europe $\quad 820$

Vlodaver, Z.: vide Sacks, M. I.

Walzl, H. L.: Ein einfaches Verfahren zur Massenkultur von Bakterien in Flüssig-

nährböden 838

Wartman, W. B.: Report on the Survey of Heart Infarction in the U.S.A. for 1 June

1964 to 31 May 1965546

Wartman, W. B.: vide Farrer-Brown, G.

Williams, R. E. O.: Staphylococcus aureus as Commensal and Pathogen 932

Wòckel, W.: vide Güthert, H.

Proceedings - Gesellschaftsberichte - Congrès

Proceedings of the Ninth Conference of the International Society of

Geographical Pathology, Leiden, September 8-10, $1966 \quad 505$

Schweizerische Mikrobiologische Gesellschaft, 26. Jahresversamm-

lung, 16. und 17. Juni 1967, in Grindelwald - Société Suisse de

Microbiologie, 26e assemblée annuelle, le 16 et 17 juin 1967, à

Grindelwald 829

Mutationen der Mitglieder der Schweizerischen Mikrobiologischen Gesellschaft im Jahre 1966/67 - Changements des Membres de la Société Suisse de Microbiologie survenus au cours de Гannée 1966/67 1060

Obituary - Nachruf - Nécrologie 
Hommage au Professeur Erwin Rutishauser 498

Notice of the Publisher - Mitteilung des Verlages - Avis de l'éditeur .... 1064

Book Reviews - Buchbesprechungen - Livres Nouveaux . . 122, 246, 392, 500, 828, 1062

Varia 256 